\title{
MICROBIOTA IN MICE CONSUMING FERMENTED LOTUS (Nymphaea pubescens) SEEDS
}

\author{
lin Khusnul Khotimah ${ }^{1}$ and Rita Khairina² \\ Faculty of Fisheries and Marine Sciences \\ Lambung Mangkurat University Banjarbaru, South Kalimantan \\ email: 1iin_kh@yahoo.co.id and 2ritasyaiful@yahoo.co.id
}

\begin{abstract}
The objective of this study was to evaluate microbiota in mice consuming fermented lotus seeds. There were two groups of mice studied, namely a group of mice given a standard diet $(\mathrm{K})$, and a group of mice given standard ration added with fermented lotus seeds (TP). The parameters measured in the study were body weight of mice, total microbes, number of BAL, and number of $E$. coli, (14- and 28- day experiments). Each observation was repeated three times. The results showed that the consumption of fermented lotus seeds did not have any effect on microbiota (the number of microbes, BAL, and $E$. coli) in mice within the 28- day experiment, but the mice lost weight as much as $2.13 \%$.
\end{abstract}

Keywords: body weight, fermented lotus seeds, mice, microbiota

\section{INTRODUCTION}

The processing process of a fermented food product involves dominant microbes like yeast, fermentative and amylolytic fungi and lactic acid bacteria (Rahayu, 2004). The fermented food is consumed directly without further cooking process that it can be categorized as a probiotic food when involving lactic acid bacteria as probiotic candidates in the processing process.

Fermented lotus (Nymphaea pubescens) seed is a fermented food with a potential as probiotic food. During the fermentation, the lactic acid bacteria and yeast are capable to grow by $10^{7} \mathrm{CFU} / \mathrm{g}$. The product is brownish in color, tastes sweet, and has strong aroma of fermentation (Khairina et al., 2007; Khotimah and Khairina, 2009). The comparison of nutritional composition of fermented lotus seed, fermented sticky rice and fermented cassava (Table 1) shows that the number of calories of fermented lotus seeds is $1.128 \%$ higher than fermented sticky rice and $1.25 \%$ higher than fermented cassava.

Table 1. Fermented Lotus Seed, Fermented Sticky Rice and Fermented Cassava

\begin{tabular}{cccccccc}
\hline \multirow{2}{*}{$\begin{array}{c}\text { Name of } \\
\text { Product }\end{array}$} & $\begin{array}{c}\text { Calorie } \\
(\text { Kal/100g) }\end{array}$ & $\begin{array}{c}\text { Bil } \\
\text { Acid }\end{array}$ & Water & Protein & Fat & Carbohydrate & Ash \\
\hline $\begin{array}{c}\text { Fermented } \\
\text { cassava }^{*}\end{array}$ & 170 & Nil & 57.35 & 6.75 & 0.50 & 34.60 & 0.80 \\
\hline $\begin{array}{c}\text { Fermented } \\
\text { sticky rice }\end{array}$ & 188 & Nil & 52.62 & 11.42 & 0.03 & 34.88 & 0.78 \\
\hline $\begin{array}{c}\text { Fermented } \\
\text { lotus seed }\end{array}$ & 212 & 0.87 & 47.22 & 5.47 & 0.39 & 46.64 & 0.28 \\
\hline
\end{tabular}

Source : $\left.{ }^{*}\right)$ Rukmini, 2003; $\left.{ }^{* *}\right)$ Fermented lotus seed according to Khairina and Khotimah, 2007.

Probiotic bacteria may provide a variety of health benefits through a variety of mechanisms. The ability of probiotic bacteria to maintain intestinal microbial balance can suppress the attack of enteric pathogens and bacteria producing carcinogenic compound. Some other benefits are to address people with intolerant lactose and chronic constipation, to lower cholesterol serum of the body, and to stimulate the body's immune system (Rahayu, 2004).

The isolation and identification of lactic acid bacteria from fermented lotus seeds resulted in three species, namely 
Streptococcus thermophillus, Pediococcus pentosaceus, and Leuconoctoc mesenteroides. The three types of BAL are resistant to kloramphenikol antibiotics $1 \mathrm{mg} / \mathrm{ml}$ and acidic condition ( $\mathrm{pH} 3)$. In the inhibition test of Streptococcus thermophillus, Pediococcus pentosaceus, and Leuconoctoc mesenteroides against enteric pathogens indicated that Streptococcus thermophillus was able to inhibit Shigella dysentery; Pediococcus pentosaceus was able to inhibit Vibrio cholera and Salmonella typhi; while Leuconoctoc mesenteroides was able to inhibit Salmonella typhi (Khotimah and Khairina, 2009).

According to Khotimah and Khairina (2010), Streptococcus thermophillus produced cell biomass as much as $2.72 \times 10^{9}$ $\mathrm{CFU} / \mathrm{ml}$, Pediococcus pentosaceus $1.2 \times 10^{10}$ $\mathrm{CFU} / \mathrm{ml}$, and Leuconoctoc mesenteroides $1.16 \times 10^{10} \mathrm{CFU} / \mathrm{ml}$. The improvement to the quality of fermented lotus seeds with the addition of native culture as much as $10^{7}$ $\mathrm{CFU} / \mathrm{ml}$ with a combination of Streptococcus thermophilus, Pediococcus pentocaceus and Leuconostoc mesentroides produced the average values of proximate (the contents of protein, fat, water, ash, and carbohydrate by $3.6475 \%, 0.56 \%, 46.66 \%, 0.305 \%$, and $46.8275 \%$, respectively), reduced sugar by $13.155 \%$, acid number $1.7375 \%$; TPC $9.87 \mathrm{x}$ $10^{8} \mathrm{CFU} / \mathrm{g}, \mathrm{BAL} 1.12 \times 10^{9} \mathrm{CFU} / \mathrm{g}$ and organoleptic (flavor, aroma, color and texture by $3.2,3.6,3.4$, and 3.4 , respectively).

The objective of this study was to evaluate the microbiota in mice consuming fermented lotus seeds. The results of the study are expected to be useful to find out the potential of fermented lotus seeds as a source of probiotics.

\section{MATERIALS AND METHODS}

\section{Materials and Equipment}

Materials used in this study were lotus seeds, yeast from Martapura, mice type of
Sprague Dawley, components of ration (AIN76A): casein, maize, sucrose, soybean oil, mineral mix, vitamin mix, and media for observations such as PCA, MRSA, Rugosa, Endo agar, TCBS, distilled water, spirtus and sterile peptone water $0.1 \%$. The equipment used was a set of tools for taking care and undergoing surgery of mice, and the devices for microbiological analysis.

\section{Steps of the Study}

Male mice of Sprague Dawley weighing $198 \mathrm{~g}-219 \mathrm{~g}$ were put in separate cages. Fifteen mice were divided into two groups, the control group consisting of nine mice while the group given fermented lotus seeds six mice.

The evaluation in mice experiment was conducted to see the effects of the consumption of fermented lotus seeds on the microbiota in mice. Fermented lotus seeds were given for 28 days by administering it to the mice using sonde. There were two (2) groups of mice studied: a group of mice given a standard diet $(\mathrm{K})$, and a group of mice given a standard ration which was added with fermented lotus seeds (TP). The number of fermented lotus seeds given to mice was converted with the assumption of the provision of $50 \mathrm{~g}$ fermented lotus seeds/ 70 $\mathrm{kg}$ human body weight. The observations of the parameters were carried out after 1,14 , and 28 days. The parameters observed were body weight of mice, total microbes, number of BAL, and number of E. coli (14- and 28day trial). Each observation was repeated three times.

\section{RESULTS AND DISCUSSION}

\section{Changes in body weight ( $\mathrm{g}$ ) of mice}

Fermented lotus seeds given to mice contained a total BAL of $1.12 \times 10^{9} \mathrm{CFU} / \mathrm{g}$ and TPC as much as $9.87 \times 10^{8} \mathrm{CFU} / \mathrm{g}$. The graph of the mice body weight growth can be seen in Figure 1. 


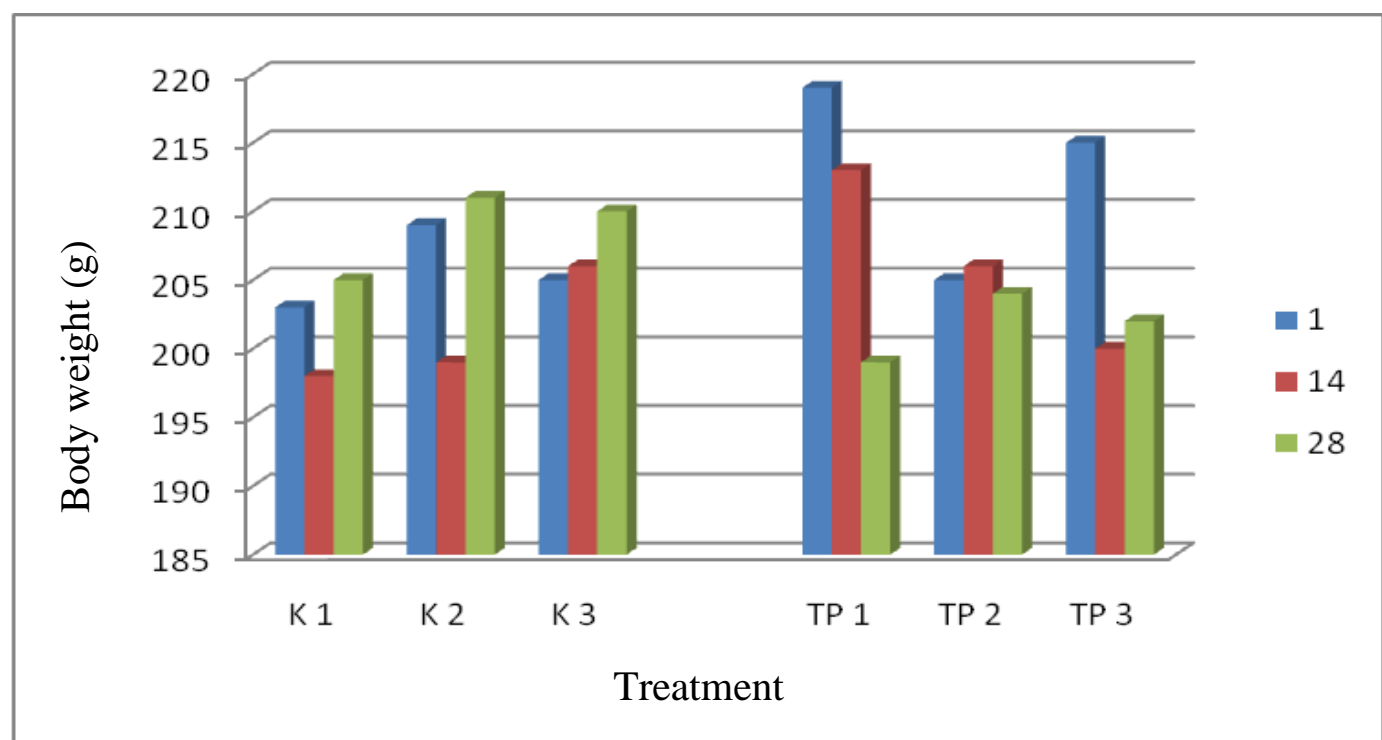

Figure 1. Changes in body weight of mice between the control group $(\mathrm{K})$ and the group given fermented lotus seeds (TP).

The maintenance of mice for 28 days demonstrated that in the control group $(\mathrm{K})$ was there a trend towards increased weight while in the group given fermented lotus seeds (TP) the weight tended to fall. The total increase/decrease in mice body weight of each group was measured from the difference between the average body weight of mice at the end of the experiment and that at the start of the experiment. The mice in control group (K) gained weight by $3 \mathrm{~g}$, whereas those in the group given fermented lotus seeds (TP) lost weight by $11.3 \mathrm{~g}$. It showed that the consumption of fermented lotus seeds for 28 days during the mice maintenance was able to lose their weight by $2.13 \%$. According to Hana (2007) the given sonde treatment did not inhibit the growth of mice, as of the groups of mice observed, the control group experienced a weight gain as much as $40.6 \mathrm{~g}$, the symbiotic group $41.7 \mathrm{~g}$, the prebiotic group $43.0 \mathrm{~g}$, and the probiotic group $47.1 \mathrm{~g}$.

\section{Number of microbes}

The number of microbes was in the range of $7.5 \mathrm{log} \mathrm{CFU} / \mathrm{g}-8.5 \mathrm{CFU} / \mathrm{g}$ of the control group (K) and $7.8 \log \mathrm{CFU} / \mathrm{g}-8.5 \mathrm{log}$ $\mathrm{CFU} / \mathrm{g}$ of the group given fermented lotus seeds (TP). The number of microbes from both groups of mice during the observations tended to decrease (Figure 2). Initially, the number of microbes for the two treatments were relatively similar; $8.5 \mathrm{log} \mathrm{CF} / \mathrm{g}$, but after having been supplied with fermented lotus seeds containing microbes amounting to 9.87 x $108 \mathrm{CFU} / \mathrm{g}$ during the 28-day experiment, the number of microbes in the control group (K) decreased to $0.3-0.9 \log \mathrm{CFU} / \mathrm{g}$ and in the group of mice given fermented lotus seeds (TP) decreased to $0.06-0.7 \log$ $\mathrm{CFU} / \mathrm{g}$. According to Hana (2007) a decrease in number of microbes during mice maintenance was probably influenced by factors causing variations in the number of microbes without outside intervention. Changes in the internal environment of the gastrointestinal tract of mice could cause changes in number of microbes from time to time. 


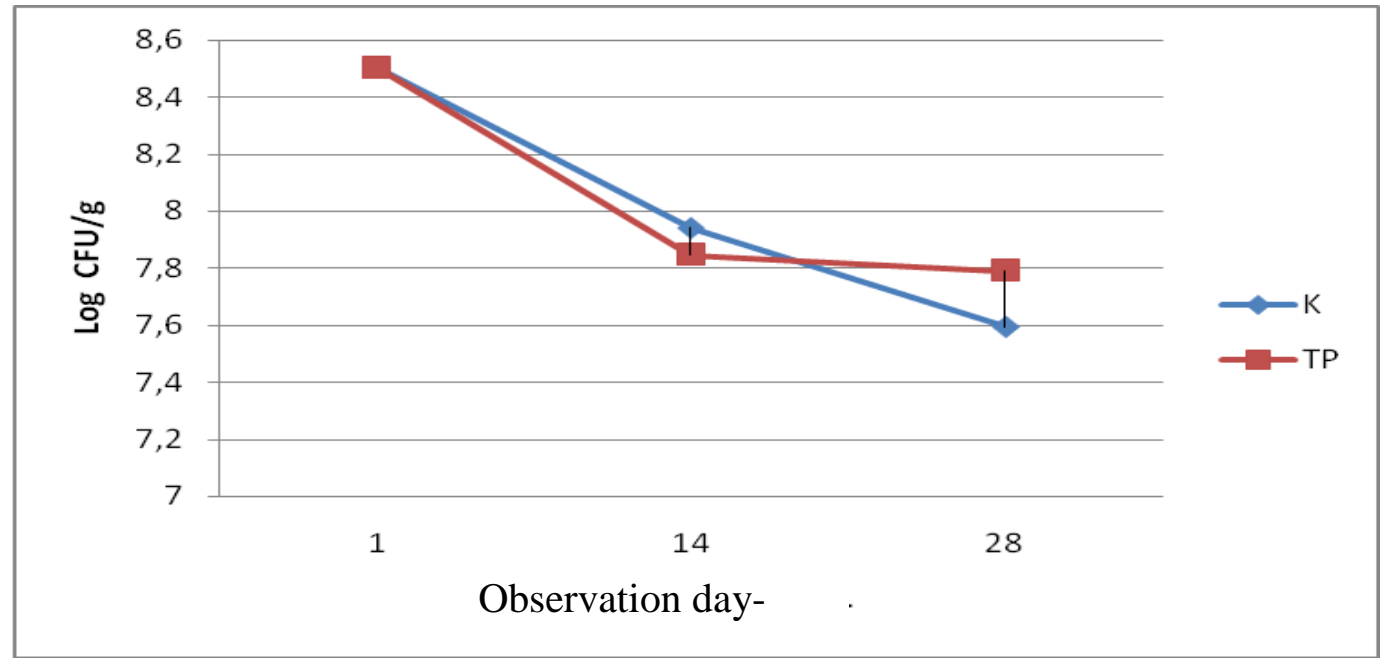

Figure 2. Number of microbes in cecum of mice for 28-day maintenance in control group $(\mathrm{K})$ and the group given fermented lotus seeds (TP).

\section{Number of lactic acid bacteria}

The number of lactic acid bacteria was in the range of $8.6 \mathrm{log} \mathrm{CFU} / \mathrm{g}-9.2 \mathrm{CFU} / \mathrm{g}$ of the control group $(\mathrm{K})$ and $8.6 \mathrm{CFU} / \mathrm{g}-9.9$ $\mathrm{CFU} / \mathrm{g}$ of the mice group given fermented lotus seeds (TP) (Figure 3 ). The number of lactic acid bacteria in the control group $(\mathrm{K})$ tended to decrease by $0.1-0.4 \log \mathrm{CFU} / \mathrm{g}$ during the mice maintenance, but that in the group given fermented lotus seeds (TP) tended to fluctuate. The number of lactic acid bacteria during the 14-day maintenance increased by $0.7 \log C F U / g$, but fell back to $0.4 \log \mathrm{CFU} / \mathrm{g}$ during the 28-day maintenance. The fluctuation in the number of lactic acid bacteria in mice given fermented lotus seeds showed that it could not provide an obvious effect on the number of lactic acid bacteria in the cecum of laboratory mice. It is suspected that the existence of a specific mechanism in the digestive tract reduced the effect of fermented lotus seeds. According to Ballongue (2004), the balance of the ecosystem of the gastrointestinal tract can be maintained through some of the factors in the physical and chemical mechanisms, and biological settings, such as intestinal peristalsis movement which can lead to the elimination of micro-organisms, and the interactions between different species of bacteria in the intestine either symbiosis or antagonist.

Lack of effectiveness of indigenous microflora from fermented lotus seeds given to the mice might be related to normal flora of mice containing enough original BAL and other bacteria, which makes it difficult for BAL to compete and adapt in the digestive tract of mice. According to Hana (2007) the mechanism and content of highly complex microflora in the digestive tract of experimental animals can cause BAL unable to adapt and compete in the gastrointestinal tract of animals. Scheinbach (1998) stated that the indigenous microflora with a very high number have adapted well to the environment of host flora, making it difficult for new entrants (BAL isolates derived from fermented lotus seeds) to compete in the attachment and nutrients. 


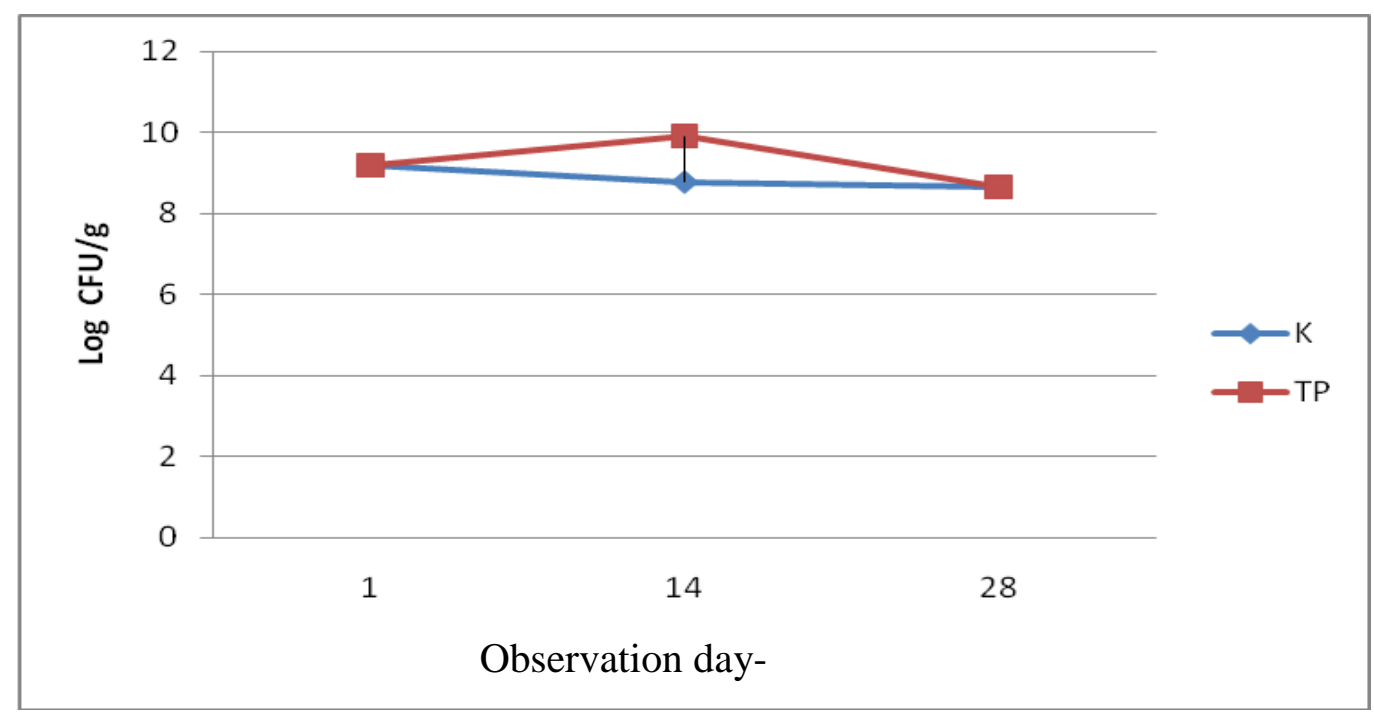

Figure 3. Number of lactic acid bacteria in the cecum of mice during 28-day maintenance in control group (K) and group given fermented lotus seeds (TP).

\section{Number of $E$. coli}

The number of $E$. coli was in the range of $5.7 \log \mathrm{CFU} / \mathrm{g}-7.7 \mathrm{CFU} / \mathrm{g}$ in the control group (K) and $5.6 \log \mathrm{CFU} / \mathrm{g}-7.3 \log \mathrm{CFU} / \mathrm{g}$ in the group given fermented lotus seeds (TP) (Figure 4). The number of $E$. coli in both groups of mice observed during maintenance tended to fluctuate similarly. The number of E. coli during 14-day maintenance decreased by $1 \log \mathrm{CFU} / \mathrm{g}$ for each group, the control group of mice $(\mathrm{K})$ and the group of mice given fermented lotus seeds (TP). After 14 days of maintenance, it showed that the number of $E$. coli in both treatments tended to increase by $2 \log \mathrm{CFU} / \mathrm{g}$ in the control group $(\mathrm{K})$ and $1.6 \log \mathrm{CFU} / \mathrm{g}$ in the group given fermented lotus seeds (TP). It shows that the number of $E$. coli gradually returns to the initial condition (day 1 ) due to the ability of normal intestinal microflora to maintain the ecological balance of the intestine (Tannock, 1999).

The results indicate that the fermented lotus seeds enriched with indigenous microflora had no effect on the number of $E$. coli in the cecum of mice. This is supported by Sundari (2002), stating that BAL only affects the number of $E$. coli cell O157: H7 attached weakly to the stainless steel while the strong cells are not affected.

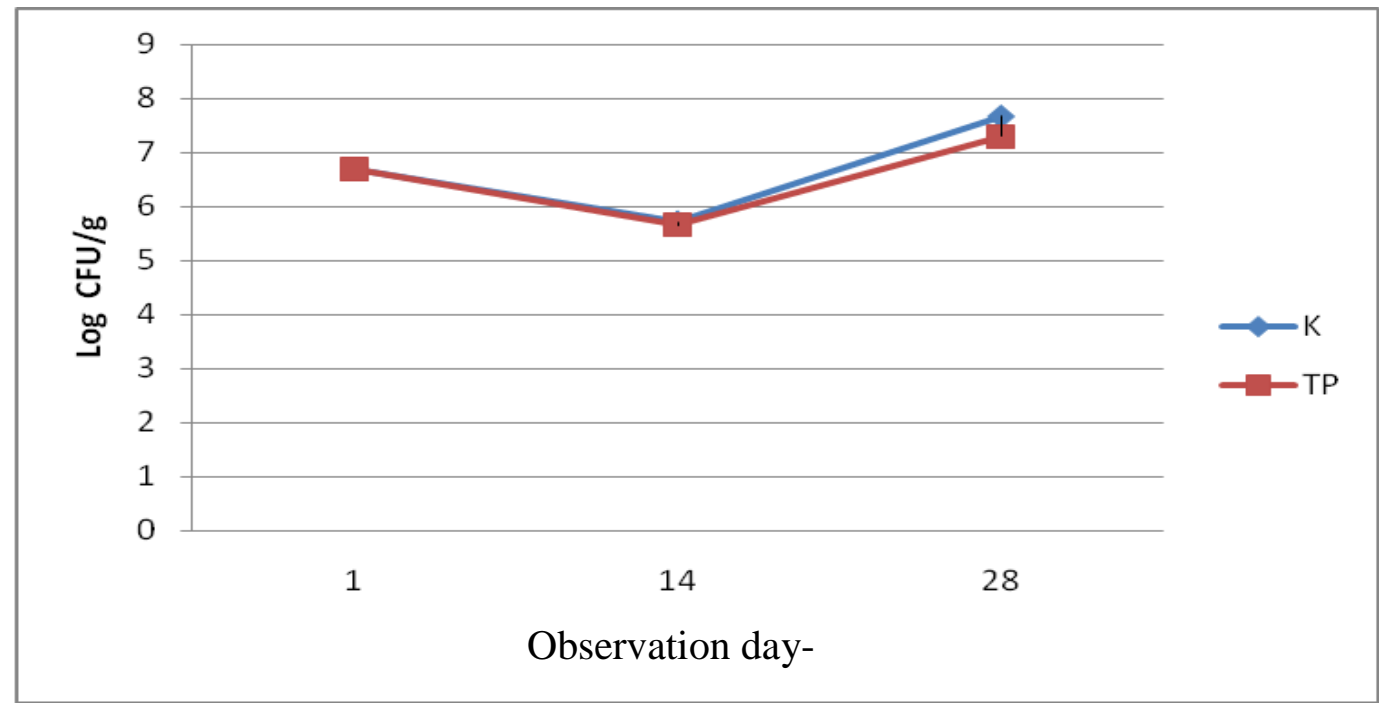

Figure 4. Number of $E$. coli in the cecum of mice for 28-day maintenance in the control group (K) and the group given fermented lotus seeds (TP). 
The provision of probiotic fermented lotus seeds is likely to be less effective for reducing $E$. coli when the number of $E$. coli is high. It is supported by the results of Evanikastri's (2003) and Meutia's (2003) stating that the provision of clinical BAL isolates cannot yet reduce the number of $E$. coli feces because the number of initial $E$. coli in mice feces is higher than that found by Suryadjaja (2005) and Hana (2007). The details can be found in Table 2 .

Table 2. Effects of BAL isolate provision on E. coli content in mice feces in some studies

\begin{tabular}{|c|c|c|c|}
\hline $\begin{array}{l}\text { Type of BAL/source } \\
\text { of BAL given }\end{array}$ & $\begin{array}{l}\text { Number of } E . \text { coli } \\
\text { feces (log CFU/g) } \\
\text { before treatment }\end{array}$ & $\begin{array}{l}\text { Number of BAL given } \\
\text { (CFU/individual/day) }\end{array}$ & Results \\
\hline $\begin{array}{l}\text { Probiotic Fermented } \\
\text { Lotus Seed }\end{array}$ & 6.7 & $1.12 \times 10^{9}$ (for 28 days) & $\begin{array}{l}\text { Had no significant effect } \\
\text { on the number of } E \text {. coli }\end{array}$ \\
\hline L. casei Rhamnosus ${ }^{b}$ & 6.9 & $2.0 \times 10^{9}$ (for 10 days) & $\begin{array}{l}\text { Had no significant effect } \\
\text { on the number of } E \text {. coli }\end{array}$ \\
\hline L. casei Rhamnosus ${ }^{c}$ & 5.9 & $6.5 \times 10^{8}$ (for 10 days) & $\begin{array}{c}\text { Number of } E \text {. coli } \\
\text { decreased by } 3 \text { log } \\
\text { CFU } / g\end{array}$ \\
\hline Lactobacillus $\mathrm{G} 1^{\mathrm{d}}$ & 7.4 & $2.0 \times 10^{9}$ (for 10 days) & $\begin{array}{l}\text { Had no significant effect } \\
\text { on the number of } E \text {. coli }\end{array}$ \\
\hline Lactobacillus B1d & 7.0 & $2.0 \times 10^{9}$ (for 10 days) & $\begin{array}{l}\text { Had no significant effect } \\
\text { on the number of } E \text {. coli }\end{array}$ \\
\hline Lactobacillus G3e & 8.0 & $10^{8}$ (for 10 days) & $\begin{array}{l}\text { Had no significant effect } \\
\text { on the number of } E \text {. coli }\end{array}$ \\
\hline Lactobacillus $\mathrm{F} 1^{\mathrm{e}}$ & 8.0 & $10^{8}$ (for 10 days) & $\begin{array}{l}\text { Had no significant effect } \\
\text { on the number of } E \text {. coli }\end{array}$ \\
\hline Lactococcus $\mathrm{K}^{\dagger}$ & 8.4 & $5.0 \times 10^{8}$ (for 10 days) & $\begin{array}{l}\text { Had no significant effect } \\
\text { on the number of } E \text {. coli }\end{array}$ \\
\hline Lactobacillus $\mathrm{F}^{\mathrm{f}}$ & 7.5 & $5.0 \times 10^{9}$ (for 10 days) & $\begin{array}{l}\text { Had no significant effect } \\
\text { on the number of } E \text {. coli }\end{array}$ \\
\hline
\end{tabular}

\section{CONCLUSION}

The consumption of fermented lotus seeds did not give any effect on the microbiota (microbial count, BAL, and E. coli) in mice during a 28-day experiment, but the mice lost weight as much as $2.13 \%$.

\section{REFERENCES}

Ananda (2003). A Study of Clinical Prebiotic Isolate Properties of Lactic Acid Bacteria in Vitro and in Vivo. Essay. The Faculty of Agricultural Technology. IPB. Bogor.

Ballongue, J. (2004). Bifidobacteria and Probiotics Action. In Salminen and A. Von Wright (eds). Lactic Acid Bacteria, Microbiology and Functional Aspect. 2nd Ed Revised and Expanded. Marcell Dekker, Inc., New York
Evanikastri (2003). Isolation and Characterization of Lactic Acid Bacteria from Clinical Samples Potentially As Probiotics. Thesis. Graduate program. IPB. Bogor.

Hana (2007). Effect of Heating on the Ability of Sugar Extract of Taro (Colocasia esculenta (L) Schott) to Support Growth of Lactic Acid Bacteria and In Vivo Evaluation of Prebiotic Potency. Essay. Department of Food Science and Technology. Faculty of Agricultural Technology. IPB. Bogor.

Khairina, R., Khotimah, I.K., and Rahayu, E.S. (2007). The Potential of Fermented Lotus (Nymphaea pubescen Willd) Seeds as Functional Food. Hibah Pekerti year I. Unlam. 65 pages.

Khairina, R., Khotimah, I.K., and Rahayu, E.S. (2008). Supplementation of 
Lactobacillus acidophilus SNP-2 in Preparing Fermented Lotus (Nymphaea pubescen Willd) Seeds. Magazine of Agricultural Science and Technology, Agritech Vol. 28 (4) : $186-191$.

Khotimah, I.K. and Khairina, R. (2009). Production of Fermented Lotus (Nymphaea pubescen Willd) Seeds As Probiotics. Competitive Grants year I. Unlam. 74 pages.

Khotimah, I.K. and Khairina, R. (2010). Production of Fermented Lotus (Nymphaea pubescen Willd) Seeds As Probiotics. Competitive Grants year II. Unlam. 62 pages.

Lee, Y.K. and Salminen, S. (1995). The Coming of Age of Probiotics Trends Food Sci. Technol. 6, 241-245.

Muetia, Y.R. (2003). Evaluation of Clinical Probiotic Potential Lactobacillus $s p$. In Vitro and In Vivo. Essay. IPB. Bogor.

Ngatidjan, (2006). Laboratory Methods in Toxicology. Pharmacology and Toxicology. Faculty of Medicine. UGM. Yogyakarta. 242 pages.

Rahayu, E.S. (2004). Fermented Food and Probiotics. Paper for Nutrigenoic and Fermented Food Seminar. Food and Nutrition Study Center UGM. Yogyakarta.

Saarella, M., Mogensen G., Fonden R., Matto J. and Mattila-Sandholm T. (2000). Probiotic Bacteria: Safety, Functional and Technological Properties. Journal Biotech 84: 197-215.

Scheinbach, S. (1998). Probiotics: Functionality and Commercial Status. Biotechnology Advances Vol. 16. No. 3. Pp $581-608$. Elsevies Science Inc.

Suryadjaja, A. (2005). Potential of White and Red Sweet Potatoes (Ipomea batatas L.) for Growth of Lactic Acid Bacteria and pressing Pathogens Growth. Essay. The Faculty of Agricultural Technology. IPB. Bogor. 